УДК $94(430+44): 911.375 \ll 04 / 10 »$

DOI: https://doi.org/10.33782/eminak2021.2(34).535

\title{
ЛЕОНІД МИКОЛАЙОВИЧ БЕРКУТ: ЕТАПИ ТВОРЧОГО ШЛЯХУ ВЧЕНОГО
}

\author{
Андрій Налівайко \\ Одеський національний університет імені I.I. Мечникова (Одеса, Україна) \\ e-mail: andrejnalivajko33@gmail.com \\ ORCID: https://orcid.org/0000-0002-5518-6637
}

У статті розкрито етапи творчого шляху українського історика, педагога, професора, викладача Київського, Варшавського та Донського університетів, видатного дослідника західноєвропейського середньовіччя - Леоніда Миколайовича Беркута (1879-1940).

Це був один з найкращих інтелектуалів свого часу. Наукові закордонні студії сприяли становленню Л. Беркута як видатного вченого та широкого популяризатора історичних знань в Україні.

На жаль, через різні життєві обставини вчений надовго був вилучений з радянського інтелектуального простору, а його наукова спадщина була забута.

Ключові слова: Л. Беркут, медієвістика, Київський університет св. Володимира, інтелектуальна історія, історіографія, джерелознавчі студії

Протягом останнього часу в українській історичній науці відбуваються значні перетворення. Вони зумовлюються різними причинами: політичними, науковими, процесами розвитку історичної науки, зміною методологічного підходу, інтеграцією української історичної науки до світового історико-історіографічного простору.

Переосмислення минулого України збільшило зацікавлення багатьма постатями, світочами української історичної науки, про яких у радянський час було майже забуто. Все це зумовило появу значної кількості традиційних біографічних досліджень, головною метою яких було відтворення здобутків біографії українських діячів.

Однак на новітньому етапі розвитку української історіографії біографічні праці поступово переходять на якісно новий рівень - від традиційного поетапного відтворення фактів біографії до інтелектуальної історії. Увага вчених зосереджується все більше на висвітленні безперервних взаємозв'язків людини та соціокультурного середовища, що їі оточує, з'ясуванні світогляду історика у його історичних поглядах, особливостей формування життєвих пріоритетів особистості ${ }^{1}$. Предметом вивчення стає не тільки історія результатів інтелектуальної творчої діяльності, але й сама історія цієї діяльності, культурне середовище, яке формує умови.

Біографія стає нібито засобом вивчення механізмів формування ментальності історика. Ідейні впливи, система освіти, політичні ідеї, коло спілкування допомагають відтворити загальну картину світосприйняття, систему фахових рис ученого ${ }^{2}$.

\footnotetext{
1 Михайленко Г.Олександр Лотоцький (1870-1939). Інтелектуальна біографія історика. Херсон, 2014. С. 6.

2 Колесник I.I. Інтелектуальне співтовариство як засіб легітимації культурної історії України XX століття // Український історичний журнал. 2008. № 1. С. 175-179.
} 
Поєднання передумов та обставин інтелектуальної біографії з індивідуальними нахилами, мотивами, пріоритетами створює презентацію наукової творчості дослідника. Тому інтелектуальна історія вивчає всі форми, засоби й інститути інтелектуального спілкування, всі продукти людського інтелектуз.

Українські діячі першої половини XX ст. усе частіше сприймаються не тільки як учасники державотворчого процесу, а й як творці європейського інтелектуального простору. Багато українців опинилися в еміграції, чимало були позбавлені політичної свободи та голосу, або ж репресовані. Але ці люди не стали спостерігачами європейського наукового життя, а були співтворцями, використовуючи свій дослід наукової, культурно-просвітницької, організаторської діяльності. Українські інтелектуали не лише творили свій, внутрішній інтелектуальний простір, а й долучалися до формування європейської інтелектуальної історії.

Відтак, історичні розвідки з вивчення персоналій видатних вчених і науковців $\epsilon$ одним з пріоритетних напрямків сучасної історичної науки. Саме даний напрямок покладено в основу нашого дослідження, яке зосереджене на постаті відомого медієвиста Леоніда Миколайовича Беркута. Що стосується стану аналізу історіографії дослідження, то про зазначеного вченого написано не надто багато. Зокрема можна виділити деякі статті Г.Ю. Баженової4, в яких, перш за все, відображається створення колективного портрету істориків Варшавського університету, а також короткі біографічні нариси О.В. Юркової5.

Сьогодні про Л.М. Беркута не написано жодної монографії, не реконструйовано інтелектуальну біографію, багато моментів з життя українського науковця лишаються невивченим. До цього часу не визначено місце вченого у розвитку медієвістики в Україні. Частково заповнити цю лакуну і призначене наше дослідження.

Леонід Миколайович Беркут (1879-1940) - український історик, педагог, професор, дослідник західноєвропейського середньовіччя та західноєвропейської історії, питань методології історії. 31928 р. доктор історії європейської культури. Він був одним із найяскравіших українських інтелектуалів свого часу. Л. Беркут, через різні життєві колізії й обставини, був надовго вилучений з інтелектуального простору СРСР, а його багатогранна наукова та літературна спадщина була забута.

Народився майбутній інтелектуал 15 червня 1879 р. (за новим стилем) в Києві у міщанській родині. На жаль, інформації про дитинство та юність Леоніда Миколайовича надто мало. Відомо лише, що середню освіту здобув у третій київський гімназії, а вищу - в Київському університеті св. Володимира 6 .

У 1901 р. Л. Беркут закінчив історико-філологічний факультет Київського університету. Роки навчання стали для нього часом напруженої роботи.

В університеті на здібного студента звернув увагу видатний учений, провідний медієвіст, професор з германістики та слав'янознавства Ф.Я.Фортинський, який

\footnotetext{
3 Верменич Я. Історія ідей та криза історизму // Ейдос. 2005. № 1. С. 24.

${ }^{4}$ Баженова Ю.А. Историки Императорского Варшавского университета 1869-1915: просвещение, политика, наука. Люблин: Instytut Europy Srodkowo-Wschodniej, 2014. C. 11.

5 Юркова О.В. Беркут Леонід Миколайович // Історичний факультет Київського національного університету імені Тараса Шевченка: минуле й сьогодення (1834-2004 рр.) / Під ред. Г.Д. Казьмирчука. Київ, 2004. С. 154.

6 Центральний держархів вищих органів влади та управління України (ЦДАВО України). Ф. 166 (Народний комісаріат освіти УСРР). Оп. 12. Спр. 483 Арк. 1зв.; Російський державний історичний архів у м. Санкт-Петербург (РДІА, СПб). Ф. 733. Оп. 226. Спр. 241. Арк. 35зв-39, 94; Державний архів Ростовської області (ДАРО) Ф. Р-46. Оп. 3. Од. 74.
} 
понад тридцять років був доцентом кафедри «загальної історії», а в останні дванадцять років свого життя й ректором університету св. Володимира.

Крім звичайних лекцій з «Історії середніх віків» професор Фортинський ввів до навчального процесу практичні заняття - «Огляд джерел середніх віків»7. Практичні заняття він проводив протягом всіх наступних років свого викладацького життя.

Маючи великий досвід викладання, отриманий у різних провідних закладах Західної Європи, професор багато уваги приділяв своїм учням, допомагав працювати над архівними джерелами, що робило його вельми популярним серед молодих студентів історико-філологічного факультету. Під впливом свого викладачанаставника Леонід Беркут зацікавився історією Рима та середніх віків. Саме тут, у Київському університеті, Л. Беркут формується як науковець.

Можливість отримати бажану професуру починалася з медальної роботи, тому що тільки золота медаль гарантувала перспективу залишитися в університеті та перейти до наступного рівня - складання магістерських іспитів. У 1901 р. закінчуючи історико-філологічний факультет, під керівництвом професора Ф.Я. Фортинського Л. Беркут здобуває золоту медаль за свою першу наукову роботу «Начерк з історії боротьби за інвеституру за часів імператора Генріха V»8. У 1905-1906 рр. талановитий випускник складає магістерські іспити.

Далі у житті Л. Беркута починається новий етап, який сьогодні вчені іменують «періодом вітчизняного туризму»9. Наукові відрядження для молодих вітчизняних вчених відкривали можливості - перш за все ознайомитися з науковими дослідженнями в закордонних університетах, оволодіти новою методою викладання спеціалізованих дисциплін, звернути увагу на допоміжні наукові установи. Основними країнами студіювання на початку XX ст. були Німеччина та Франція. Згідно 3 правилами міністерства наукові відрядження тривали два роки та здійснювалися за державний кошт. Завдяки рішенню Наукової ради університету Л. Беркут дістав закордонне відрядження для поглиблення своїх знань у галузі всесвітньої історії (середньовічної та римської) ${ }^{10}$.

Протягом 1907-1909 рр. Л. Беркут працював у різних наукових закордонних закладах під безпосереднім керівництвом провідних вчених. Найбільшу увагу для його спеціалізації мало студіювання у Паризькій «Школі хартій». Створена у 1821 р. для підготовки архівістів і бібліотекарів, здатних працювати з документами з історії середньовічної Франції, вона відіграла величезну роль у розвитку палеографії, дипломатики й інших допоміжних історичних дисциплін, а також у вивченні неопублікованих джерел. Тут Л. Беркут вивчав дипломатику та палеографію у видатного французького професора А. Жірі. Саме концепція Жірі вплинула на наступні роботи з питань методології джерелознавства. А. Жірі визначив об'єкт дослідження дипломатики, віднісши до її компетенції такі види джерел, як дипломи, грамоти, акти, правові документи, а в методі їх вивчення порушив питання їх належності до автора 11.

\footnotetext{
7 Лиман С. Ф.Я. Фортинський у Франції: з історії його зарубіжної подорожі 1874-1876 pp. // Наукові праці Камянець-Подільського у-ту імені І. Огієнка: історичні науки. 2015. Т. 25. С. 114.

${ }^{8}$ Беркут Л. Очерк из истории борьбы за инвеституру во время императора Генриха V. Генрих V и Пасхалпс II до конкордата. Киев, 1902. 96 с.

9 Лиман С. Вказ. праця. С. 109.

10 ЦДАВО України. Ф. 166 (Народний комісаріат освіти УСРР). Оп. 12. Спр. 483.

11 Медушевская О.М. Собрание сочинений в 4-х томах. Т. 2: Источниковедение: теория история, метод. Москва, Берлин: Директ-Медиа, 2017.
} 
У 1908 р. Л. Беркут вивчав середньовічну латинську палеографію на семінарі професора Гавка. Далі у Мюнхені цю ж дисципліну слухав, відвідуючи семінари дійсного члена Баварської академії наук проф. Генріха Сімонсфольда. У Грайфсвальдському університеті Л. Беркут відвідував курси з методології історії відомого Ернста Бернгейма, автора «Підручника історичного методу і філософії історії». У цьому ж університеті брав участь у семінарі ще одного німецького історика, відомого своїми працями з історії пізньої античності, Отто Зеєка.

Наприкінці 1908 р. Л. Беркут прослухав спецкурс одного з першокласних юристів свого часу, вченого, діяльність якого охоплювала римське, німецьке та церковно-канонічне право, проф. Рудольфа Зома. Надалі концепцію цього вченого у загальних рисах буде вживати український вчений в описанні взаємозв'язку церкви і західних держав на етапі раннього середньовіччя. Історію Католицької церкви та папства Л. Беркут вивчав у студіях церковного дослідника, провідного теолога Марбурзького університету Карла Мірбта.

Переїхавши з Німеччини до Парижа, вчений відвідував Практичну школу вищих досліджень, яка займала декілька приміщень Сорбони, де основою навчання проголошувалися практичні заняття, а також College de France. У Франції на його заняття мали вплив видатні спеціалісти - професори Гастон Блок, Люшер, Флак 12 .

Отже протягом 1907-1909 рр. Л. Беркут став однією з найяскравіших фігур молодого покоління вчених, домігся серйозних успіхів у кількох гуманітарних дисциплінах: палеографії, дипломатики, джерелознавства, а провідні вчені Німеччини та Франції мали істотний вплив на всю його подальшу наукову діяльність.

У 1909 р. Л.М.Беркут повертається до Києва та здобуває звання приватдоцента. Цього ж самого року його було обрано на посаду штатного доцента Варшавського університету по кафедрі всесвітньої історії, яка у той час залишалася вакантною через переїзд до Москви ще одного вихованця Київського університету, знавця англійської середньовічної історії проф. Д.М. Петрушевського.

В 1915 р. Л. Беркута було обрано на посаду екстраординарного професора цього ж університету 13 .

В період свого викладання у Варшаві Л. Беркут розробив курси лекцій «Історія середніх віків»14, «Вступ до історії середніх віків»15, а також «Історія Франції XVIII ст.»16, які він читав слухачам перших і других курсів історико-філологічного відділення Варшавських жіночих курсів.

Взагалі матеріал цих лекцій характеризує Л. Беркута як першокласного знавця латини й інших європейських мов. Протягом розкриття усіх лекційних тем фігурує величезна кількість латинських термінів і понять. Вченого вирізняє високий рівень ерудиції, прекрасне знання європейської культури.

Л. Беркут вважав, що головний інтерес у вивченні середньовічної історії Західної Європи IX-XIII ст. полягає у вивченні католицизму та феодалізму. Саме ці гілки культурного та соціального життя допомагають виділити середньовіччя в особливий відділ історії не тільки для романських і германських народностей, а й для

\footnotetext{
12 Левченко М. Леонид Миколайович Беркут (з нагоди 25-их роковин наукової діяльності) // Записки історично-філологічного відділу [УАН]. Кн. 16. Київ, 1928. С. 280.

13 Баженова Ю.А. Историки Императорского Варшавского университета... С. 11.

14 Беркут Л. Лекции по истории средних веков. Варшава, 1910/1911. 236 с.

15 Беркут Л. Введение в историю средних веков. Варшава, 1911. 80 с.

16 Беркут Л. Лекции по истории Франции XVII в. Варшава, 1910. 46 с.
} 
слов'янських, котрі духовно примкнули до романо-германського світу та його католицько-феодальної культури ${ }^{17}$.

Деякі матеріали цих лекцій стали основою подальших публікацій молодого вченого, таких як: «Карл Великий и франкская образованность и литература его времени» (1912) ${ }^{18}$, «Христианские легенды и жития святых раней епохи средних веков» ${ }^{19}$, «Императорские привилегии и городские права XII в. в Германии»20 та багато інших.

Характерною рисою не тільки лекцій, а й подальших наукових видань Л. Беркута $є$ чітке зосередження на темі, аналіз біографій історичних персонажів, вивчення культурної атмосфери тощо.

Все це свідчить, що Л. Беркут був спадкоємцем найкращих наукових традицій XIX - поч. XX ст., адже у своїх поглядах завжди був прибічником аналізу першоджерела. Саме цей принцип став основою наукової діяльності на все подальше життя. У цілому ж лекції демонструють його як викладача з широкою площиною мислення, допомагають нам проникнути у його духовний світ.

Після Першої світової війни науковець разом з іншими працівниками Варшавського університету був евакуйований до Донського державного університету в Ростові. Тут він займав різні відповідальні адміністративно-педагогічні посади. Так, у 1918-1919 рр. він був секретарем, а далі і заступником директора Донських вищих жіночих курсів, а у 1920-1921 pр. - помічником декана. У кінці 1921 р. Л. Беркут переїжджає до Києва21.

Перша Світова війна суттєво дезорієнтувала освітній процес. Багато студентів опинилися у діючій армії, а сам університет було евакуйовано до Самари і тільки у 1916 р. університет повернувся до Києва.

Після ліквідації самодержавства, на вимогу української інтелігенції, 19 вересня 1917 р. «Тимчасовий уряд» прийняв постанову про створення чотирьох українознавчих кафедр: української мови, літератури, історії, західного руського права. Однак, на жаль, подальші політичні перипетії відтіснили науковий процес на задній план 22.

Після зайняття більшовиками Києва 1919 р. та внаслідок реформ «Народного комісаріату освіти» УСРР 1920 р. Київський університет було розформовано. 3 історико-філологічного і фізико-математично-природничого факультетів університету Київського учительського інституту та Київських вищих жіночих курсів було створено Вищий інститут народної освіти імені М. Драгоманова, а з 1926 р. - Київський інститут народної освіти (IHO). У 1922 р. Київський IHO запропонував Л. Беркуту обійняти посаду керівника кафедри Всесвітньої історії, яку він й обіймав, але вже у перейменованому (з 1933 р.) Київському державному університеті до самої смерті (†1940р.). Недовгий час (1923-1924 рр.) Л. Беркут був навіть обраний деканом факультету професійної освіти Київського IHO23.

\footnotetext{
17 Беркут Л. Введение в историю средних веков... С. 5.

18 Беркут Л. Карл Великий и франкская образованность и литература его времени. Историографический этюд. Варшава, 1912. 48 с.

19 Беркут Л. Жития святых. Из записок по источниковедению средней истории. Варшава, 1911. $32 \mathrm{c}$.

20 Беркут Л. Императорские привидлегии и городские права XII в. в Германии. Варшава, 1910. 14 с. 21 ДАРО. Ф. Р-46. Оп. 1. Спр. 521. Арк. 2; Оп. 3. Спр. 368. Арк. 26; Оп. 3. Спр. 74. Арк. 21.

22 Киевский университет в период украинской революции (1917-1919). URL: http://www.univ.kiev.ua/ru/geninf/history 23 ЦДАВО України. Ф. 3561 (Особовий фонд проф. Оглоблина). Оп. 1. Спр. 269.
} 
Одразу після свого переїзду до Києва Л. Беркут входить у міцні зв’язки з українськими науковими колами, активно сприяє українізації своєї кафедри. 3 перших років перебування у Києві він виявив себе як надзвичайний прихильник української культури, багато працював для прищеплення на «українському грунті» всесвітньої історії 24.

У період свого професорства Л. Беркут, окрім основних курсів з історії середніх віків і Риму, викладав і чимало інших авторських розробок: джерелознавство середньовічної історії, методологія історії, історія середньовічних міст, історія середньовічної латинської літератури та латинська палеографія з дипломатикою, історія французького абсолютизму та історія Англії за нових часів. Деякий час викладав історичний матеріалізм.

Треба зазначити, що в умовах сталінських репресій науковець був змушений оволодіти марксистко-ленінською методологією та друкувати ідеологічно «правильні» статті. Проте його роботи не можна назвати кон'юнктурними чи виконаними на замовлення, Л. Беркут завжди писав з позиції вченого, а не відданого марксиста 25 .

Незважаючи на постійну напружену наукову роботу, Л. Беркут багато часу й уваги приділяв вихованню студентства. Прикладом його педагогічної діяльності служать «семінари підвищеного типу», метою яких була наукова підготовка майбутніх дослідників. Однією з багатьох секцій семінару, а саме секцією всесвітньої історії, керував саме Л.М. Беркут. Цікаво, що даючи для розробки теми співробітникам секції, професор враховував не лише їх методологічне значення чи індивідуальні інтереси, а й здібності своїх слухачів. Для Л. Беркута було важливо, щоб студенти не тільки вміли використовувати весь науковий матеріал, а, головне, навчились робити самостійні висновки 26.

Вивчаючи педагогічну діяльність Л. Беркута, хочеться відзначити одну, на наш погляд, цікаву річ. А саме, зв'язок з історичним факультетом Одеського національного університету імені I.I. Мечникова. Перед початком Другої світової війни у Київському державному університеті, секретарем студентського гуртка з історії середніх віків, яким керував Л. Беркут, була Ірина Володимирівна Зав'ялова (19112001), блискучий викладач-ерудит, доцент кафедри історії стародавнього світу та середніх віків.

Довгий час працюючи на історичному факультеті Одеського університету, I.В. Зав'ялова вела науковий студентський гурток з історії культури епохи Відродження, прививаючи молодим студентам любов до мистецтва та літератури Ренесансу. Як відзначають безпосередньо учасники цього гуртка, доповіді на заняттях відрізнялися високим науковим рівнем. Багато хто задавав собі питання звідки така ерудиція, звідки така школа?! Тоді молоді студенти історичного факультету і гадки не мали, що проходить передача незримого факела27.

Почесні заслуги Л.М. Беркута часто були відзначені різними науковими закладами. У Мюнхенському університеті він отримав ступінь кандидата філософії, у

\footnotetext{
24 Юркова О.В. Беркут Леонід Миколайович... С. 154.

25 Беркут Л. Буржуазні концепції і марксистсько-ленінське розуміння так званих середніх віків // Україна. 1933. № 1-2. С. 25-60.

26 ЦДАВО України. Ф. 3561. Оп. 1. Спр. 269, 359.

27 Немченко И.В. Ирина Владимировна Завьялова: страницы биографии // Libra: збірка наукових праць кафедри історії стародавнього світу та середніх віків. Вип. II. Одеса, 2012. С. 11.
} 
Харківському - ступінь магістра всесвітньої історії, від Комісії для присуду вчених ступенів при Академії наук ступінь доктора історії західноєвропейської культури. Протягом останнього десятиліття своєї наукової діяльності Л. Беркут підготував до друку дві свої знамениті монографії: «Етюди з джерелознавства середньовічної історії» та «Нариси історії середньовічної історіографії». Окрім своєї наукової вартості, вони мають особливе значення для української культури, тому що одні з небагатьох наукових монографій першої половини XX ст. вийшли у світ українською мовою 28.

Отже, реконструкція інтелектуальної біографії Леоніда Миколайовича Беркута (1879-1940) дозволяє простежити історичні аспекти різних видів його наукової та творчої діяльності, розширити відомості про формування його історичних студій. Наукові історичні дослідження Л. Беркута з медієвістики мають високий науковий рівень та є яскравою презентацією епохи, що містять досить багатих фактичній матеріал.

Але, на жаль, Л.М. Беркут не є загальновідомим українським вченим і саме тому на сьогодні перед дослідниками постало питання остаточного повернення Л. Беркута в науку, адже його наукові розвідки залишаються і досі актуальними для вивчення історії середньовіччя.

Леонід Миколайович $є$ не просто недооцінений і призабутий інтелектуал, він вчений світового рівня й українське надбання.

\section{REFERENCES}

Bazhenova, Yu.A. (2014). Istoriki Imperatorskogo Varshavskogo universiteta 1869-1915: prosveshchenie, politika, nauka [Historians of the Imperial University of Warsaw 1869-1915: education, politics, science]. Liublin: Instytut Europy Srodkowo-Wschodniej [in Russian]

Berkut, L. (1910/1911). Lektsii po istorii srednikh vekov [Lectures on the history of the Middle Age]. Varshava [in Russian].

Berkut, L. (1910). Vvedenie v istoriiu srednikh vekov [Introduction to the history of the Middle Ages]. Varshava [in Russian].

Berkut, L. (1910). Lektsii po istorii Frantsii XVII v. [Lectures on the history of France in the 17th century]. Varshava [in Russian].

Berkut, L. (1912). Karl Velikii i frankskaia obrazovannost i literatura ego vremeni. Istoriograficheskii etiud [Charlemagne and Frankish education and literature of his time. Historiographic sketch]. Varshava [in Russian].

Berkut, L. (1911). Zhytiia sviatykh. Iz zapisokie po istochnikoviedeniiu srednei istorii [Lives of the Saints. From the notes on the source study of the middle history]. Varshava [in Russian].

Berkut, L. (1910). Imperatorskie privedlegii i gorodskie prava XII v. v Germanii [Imperial habits and city rights of the XII century in Germany]. Varshava [in Russian].

Berkut, L. (1933). Burzhuazni kontseptsii i marksystsko-leninske rozuminnia tak zvanykh serednikh vikiv [Bourgeois concepts and the Marxist-Leninist understanding of the so-called Middle Ages]. Ukraina, 1-2 [in Ukrainian].

Kolesnyk, I.I. (2008). Intelektualne spivtovarystvo yak zasib lehitymatsii kulturnoi istorii Ukrainy XX stolittia [Intellectual community as a means of legitimizing the cultural history of Ukraine of the XX century]. Ukrainskyi istorychnyi zhurnal, 1, 175-179 [in Ukrainian].

Kyiv National University (N.d.). Kieskiy universitet v period ukrainskoi revoliutsii (1917-1919) [Kyiv University during the Ukrainian Revolution (1917-1919)]. Retrieved from http://www.univ.kiev.ua/ru/geninf/history [in Russian].

Levchenko, M. (1928). Leonid Mykolaiovych Berkut (z nahody 25-ykh rokovyn naukovoi diialnosti) [Leonid Mykolaiovych Berkut (on the occasion of the 25th anniversary of scientific activity)]. Zapysky istorychno-filolohichnoho viddilu [UAN], (Vol. 16, pp. 280-283). Kyiv: UAN [in Ukrainian].

Lyman, S. (2015). F.Ya. Fortynskyi u Frantsii: z istorii yoho zarubizhnoi podorozhi 1874-1876 rr.

28 Левченко М. Леонид Миколайович Беркут... С. 281-283. 
[F.Ya. Fortinsky in France: from the History of his foreign travels in 1874-1876]. Naukovi pratsi Kamianets-Podilskoho universytetu imeni I. Ohiienka: istorychni nauky. Vol. 25, P. 109-117 [in Ukrainian].

Medushevskaia, O.M. (2017). Sobranie sochineniy. Vol. 2: Istochnikovedenie: teoriya istoriia, metod [Collected works. Vol. 2: Source's study: theory, history, method]. Moskva-Berlin [in Russian].

Mykhailenko, H. (2014). Oleksandr Lototskyi (1870-1939). Intelektualna biohrafiia istoryka [Alexander Lototsky (1870-1939). Intellectual biography of the historian]. Kherson [in Ukrainian].

Nemchenko, Y.V. (2012). Irina Vladimirovna Zavialova: stranitsy biografii [Irina Vladimirovna Zavyalova: biography pages]. Libra: zbirka naukovykh prats kafedry istorii starodavnoho svitu ta serednikh vikiv. Vol. II. Odesa, pp. 7-13 [in Russian].

Vermenych, Ya. (2005). Istoriia idei ta kryza istoryzmu [History of ideas and crisis of historicism]. Eidos, 1, $24-27$ [in Ukrainian].

Yurkova, O.V. (2004). Berkut Leonid Mykolaiovych [Leonid Mykolaiovych Berkut]. In Kazmyrchuk, H.D. (Ed.). Istorychnyi fakultet Kyivskoho natsionalnoho universytetu imeni Tarasa Shevchenka: mynule i sohodennia (1834-2004 rr.). Kyiv, P. 154 [in Ukrainian].

\section{Andrey Nalivaiko}

(Odessa I.I. Mechnikov National University, Odesa, Ukraine)

e-mail: andrejnalivajko33@gmail.com

ORCID: https://orcid.org/0000-0002-5518-6637

\section{Leonid Mykolaiovych Berkut: Stages of Scholar's Creative Path}

The stages of the intellectual biography of Ukrainian scholar L.M. Berkut (1879-1940) are studied in the paper.

L. Berkut was a student of the famous medievalist, Rector of the Imperial University of St. Vladimir, prof. F. Fortynskyi. In 1901 he was left at the university to write a master's thesis on medieval history. After passing the master's exam, the young scholar was sent by the Ministry of National Education to Germany and France for three years to continue his scientific studies (1907-1909). He studied different periods of medieval history under such prominent scholars of that time as Ernst Bernheim, Albert Hawke, and others.

After returning from abroad, he immediately became an acting associate professor at the University of Warsaw, then worked at Don University, and in 1922 returned to his native Kyiv University.

The scientific heritage of the historian can be divided into two parts: the first is work on medieval historiography and source studies, the second - works on medieval urban studies.

The main achievement of L. Berkut's works is the analysis of a wide range of sources and literature. Unfortunately, due to various life collisions and circumstances, Ukrainian professor was removed from the intellectual space of the USSR for a long time, and his scientific heritage was forgotten.

Keywords: L. Berkut, medieval studies, scientific studies, source studies, intellectual history, Kyiv University, Ukrainian scientific tourism 